\title{
Diagnosis of Neospora caninum in bovine fetuses by histology, immunohistochemistry, and nested-PCR
}

\author{
Pesquisa de Neospora caninum em fetos bovinos por histologia, imunoistoquímica e nested-PCR \\ Aline Diniz Cabral ${ }^{1 *}$; Clarice Neves Camargo ${ }^{1}$; Nara Thiers Cacciatori Galleti' ${ }^{1}$; Liria Hiromi Okuda ${ }^{1}$; \\ Edviges Maristela Pituco ${ }^{1}$; Claudia Del Fava ${ }^{1}$
}

${ }^{1}$ Instituto Biológico, Centro de Pesquisa e Desenvolvimento de Sanidade Animal - CPDSA

Received February 20, 2009

Accepted July 2, 2009

\begin{abstract}
Neospora caninum, a cause of abortion and stillbirth in cattle, was studied by histology, immunohistochemistry, and nested-PCR, using primers from the Nc5 region of the genomic DNA (PCR PLUS) and primers from the ITS1 region of the ribosomal DNA (PCR JB). A total of 105 fetal samples sent to the Centro de Pesquisa e Desenvolvimento de Sanidade Animal do Instituto Biológico from January 2006 to May 2008 were examined for evidence of N. caninum. Histological examination revealed $71.4 \%$ with non-suppurative inflammation in the heart, lung, liver, kidney, placenta, and brain. Immunohistochemistry detected infections in $8.6 \%$ of the samples, mainly in the brain, placenta, and heart. Nested-PCR JB revealed $6.7 \%$ with infections, while nested-PCR PLUS returned $20.9 \%$ positive results, mainly in brain and placenta, and in the pooled liver and heart. Kappa statistics demonstrated little agreement among the three techniques. The three methods are complementary, since they have distinct diagnostic characteristics and were combined to give a positivity rate of $24.8 \%$.
\end{abstract}

Keywords: Neosporosis, abortion, cattle, Brazil, diagnosis.

\section{Resumo}

Pesquisou-se Neospora caninum como causador de abortamento e natimortalidade em bovinos, por meio de exame histopatológico (hematoxilina-eosina), imunoistoquímica (IHQ) e nested-PCR, utilizando primers da regiáo Nc5 do DNA genômico (PCR PLUS) e primers da regiáo ITS1 do DNA ribossomal (PCR JB). Foram avaliadas 105 amostras de abortamento bovino entre janeiro de 2006 a maio de 2008, encaminhadas ao Centro de Pesquisa e Desenvolvimento de Sanidade Animal do Instituto Biológico para diagnóstico diferencial de causas infecciosas. Observou-se em 71,4\% das amostras lesões histológicas (HE) caracterizadas pela presença de células inflamatórias mononucleares no coração, pulmão, fígado, rim, placenta e cérebro. A IHQ detectou $8,57 \%$ de positividade, sendo maior no cérebro, placenta e coração. A nested-PCR JB revelou 6,66\% de casos positivos, enquanto que a nested-PCR PLUS apresentou maior taxa de positividade (20,95\%), principalmente no cérebro, placenta e no pool fígado/coração. Houve baixo grau de concordância entre as três técnicas pelo índice kappa. A taxa de positividade para qualquer uma das técnicas (IHQ, nested-PCR PLUS e nested-PCR JB) foi de 24,8\%, devendo ser consideradas conjuntamente pelo fato de possuírem características distintas e serem, portanto, complementares no diagnóstico definitivo da neosporose.

Palavras-chave: Neosporose, aborto, bovino, Brasil, diagnóstico.

\section{Introduction}

Neospora caninum is a protozoan belonging to the phylum Apicomplexa. It was first detected in dogs in Norway (BJERKÅS; MOHN; PRESTHUS, 1984), and was described and named in 1988 by Dubey et al. Studies by McAllister et al. (1998)

\footnotetext{
*Corresponding author: Aline Diniz Cabral

Mestre em Sanidade, Segurança Alimentar e Ambiental no Agronegócio,

Instituto Biológico, Rua Conselheiro Rodrigues Alves 1.252,

Vila Mariana, CEP 04014-002 São Paulo - SP, Brasil;

e-mail: alinedica@netsite.com.br;

Supported by: FAPESP 06/55700-3/Scholarship TT-3 FAPESP n.06/55701-0
}

showed that the domestic dog is a definitive host, as is the coyote (Canis latrans) (GONDIM et al., 2004a). It was subsequently identified as a causal agent of abortion and stillbirth in cattle (THILSTEAD; DUBEY, 1989), and later studies demonstrated its worldwide economic impact (DUBEY; LINDSAY, 1996; ANDERSON et al., 1991).

The most important clinical sign of neosporosis is abortion, occurring during the $5^{\text {th }}-6^{\text {th }}$ month of gestation, sporadically, endemically, or epidemically. Congenital transmission ranges from 50 to $95 \%$ and plays an important role in maintenance of 
the parasite in herds (WOUDA et al., 1997; SCHARES et al., 1998).

The successful diagnosis of $N$. caninum-related abortion depends on necropsy of aborted fetuses to collect brain tissue, pleuroperitoneal fluids, and blood serum, along with the placenta and serum from the mother for histopathological, microbiological, and parasitological analysis (KIRKBRIDE, 1990).

The first identification of $N$. caninum in an aborted fetus in Brazil was performed by Gondim et al. (1999). Santos et al. (2005) examined 34 individuals (fetuses and stillbirths) from Paraná State histologically and detected 8 positive for $N$. caninum using immunohistochemistry (IHC).

Corbellini et al. (2002) evaluated 46 aborted fetuses from the State of Rio Grande do Sul, Brazil by histology and IHC. They found 22 with non-suppurative inflammation, mainly in the heart and brain. Fetal encephalitis presented in some cases, with focal necrosis infiltrated by mononuclear inflammatory cells. The IHC was positive in $39.1 \%$ of the fetuses.

Paula et al. (2004), found a 31.3\% (10/32) positive rate for $N$. caninum in the brain of aborted fetuses using PCR based on primers to Nc5 gene.

Pescador et al. (2007), in Rio Grande do Sul, South Brazil, conducted histological examination of 258 aborted fetuses and found lesions suggestive of protozoan infection in 89 (34\%) (nonsuppurative myositis, nonsuppurative myocarditis, nonsuppurative pneumonia associated with focal cellular necrosis, and multifocal necrotizing nonsuppurative encephalitis). Immunohistochemistry revealed tachyzoites and cysts of $N$. caninum in $55(61.8 \%)$ of these 89 fetuses. However, autolysis in the brain precluded presumptive diagnosis made by histopathology in $53 \%$ of the fetuses examined. These results indicate that when the fetal brain is autolyzed, the lung may be adequately used for the presumptive diagnosis of $N$. caninum infection. The result also confirmed that, even autolyzed, the brain is the most suitable organ for anti- $N$. caninum IHC.

Several PCR-based methods have been developed, focusing on the ITS1 region and the Nc5 sequence specific for $N$. caninum, as nested- or hemi-nested-PCR, aimed at improving sensitivity and specificity (COLLANTES-FERNÁNDEZ et al., 2002).

The aim of the present study was to diagnose $N$. caninum in aborted bovine fetuses using IHC and nested-PCR (primers of the ITS1 region of the parasite and the Nc5 sequence), as well as on the basis of histopathological lesions in several fetal organs and the placenta.

\section{Materials and Methods}

\section{Clinical samples}

One hundred and five samples from bovine abortions were sent to the Centro de Pesquisa e Desenvolvimento de Sanidade Animal do Instituto Biológico for diagnosis, from January 2006 to May 2008. Samples were screened for $N$. caninum in the brain, heart, kidney, liver, lung, spleen, thymus, and placenta, using histology, IHC, and nested-PCR. Samples did not include all organs from every fetus, and not all samples received were suitable for analysis.

\section{Histopathology and immunohistochemistry}

Tissues were fixed in $10 \%$ buffered formalin, embedded in paraffin, cut at $4 \mu \mathrm{m}$, and stained with hematoxylin and eosin (HE) for routine histology. A second set of sections were mounted on slides, along with controls, and processed for IHC using avidin-biotin-complex peroxidase (Vector Elite $\mathrm{ABC}$-peroxidase ${ }^{\circledR}$ ) (LINDSAY; DUBEY, 1989). The positive control was fetal heart taken from a pregnant goat that had been inoculated with the Illinois-NC strain of $N$. caninum. The same heart tissue was used as a negative control when it was not exposed to the primary antibody. All slides were hydrated and endogenous peroxidase was blocked by a mix of $10 \mathrm{~mL}$ of hydrogen peroxide $30 \mathrm{vol} ., 10 \mathrm{~mL}$ methanol, and $80 \mathrm{~mL}$ buffer. They were placed in a microwave oven ( 800 watts) for 10 minutes for antigen retrieval. Non-specific reactions were blocked with 10\% milk powder dissolved in PBS.

The primary polyclonal antibody, anti- $N$. caninum rabbit hyperimmune serum, was diluted 1:2000. The DAB chromogen (Data Sheet-Liquid DAB Substrate Pack, concentrated - BIOGENEX ${ }^{\circledR}$ ) was used for display and disclosure of the reaction. Sections were counterstained with Mayer's hematoxylin and examined microscopically.

\section{Polymerase chain reaction}

The genomic DNA was extracted from fresh and frozen tissues, using a commercial kit (Wizard Genomic DNA Purification Kit - Promega $\left.{ }^{\circledR}\right)$, following the manufacturer's instructions. DNA hydration solution $(100 \mu \mathrm{L})$ was added to the pellet, which was heated for 1 hour at $64^{\circ} \mathrm{C}$. Samples were stored at $-20^{\circ} \mathrm{C}$ until the completion of the nested-PCR.

Two nested-PCR protocols were conducted using primers from the Nc5 region of the genomic DNA (PCR PLUS) and primers from the ITS1 region of the ribosomal DNA (PCR JB). For the nested-PCR PLUS, pairs of NP21 PLUS-NP6 PLUS primers (5' GGGTGTGCGTCCAATCCTGTAAC 3' - 5' CTCGCCAGTCAACCTACGTCTTCT 3') were used to amplify the 337 bp DNA fragment and NP6-NP7 (5 'CAGTCAACCTACGTGTTAT 3' - 5' GGGTGAACCGAGGGAGTTG 3'), which amplified 227pb of the Nc5 gene of $N$. caninum (HUGHES et al., 2006). Five $\mu \mathrm{L}$ of the DNA sample were added to the PCR mix made up to a final volume of $20 \mu \mathrm{L}$ with commercial buffer from the kit Promega PCR Master $\mathrm{Mix}^{\mathrm{TM}}(\mathrm{M} 7502)$ and $0.2 \mu \mathrm{M}$ of each primer. The amplification was a modification of Hughes et al. (2006). The first amplification was 1 cycle of $95^{\circ} \mathrm{C}$ for 5 minutes, 40 cycles of $94^{\circ} \mathrm{C}$ for 1 minute, $60{ }^{\circ} \mathrm{C}$ for 1 minute, $72{ }^{\circ} \mathrm{C}$ for 1 minute, and 1 cycle of $72^{\circ} \mathrm{C}$ for 10 minutes and maintenance at $4^{\circ} \mathrm{C}$. The second amplification was the same, using $5 \mu \mathrm{L}$ of the first amplification product.

For nested-PCR JB, pairs of JB1 - JB2 primers (5'-AGGAAGGAGAAGTCGTAACAAGG-3' and 5'-GAGCCAAGACATCCATTGC-3') were used to amplify the 500 bp DNA fragment and SF1 - SF2 (5 '-CCTGTGAGTTGTATCGCCTTC-3' and 5'-TCTCTTCCCTCAAACGCTATCC-3') to amplify $250 \mathrm{bp}$ of the 
ITS1 region of ribosomal DNA from $N$. caninum (BARRATT et al., 2008). Five $\mu \mathrm{L}$ of the DNA sample was added to the PCR mix, and a final volume of $20 \mu \mathrm{L}$ was made with buffer from the commercial kit Promega PCR Master Mix ${ }^{\text {TM }}$ (M7502) and $0.5 \mu \mathrm{M}$ of each primer. The amplification was a modification of Barratt et al. (2008). The first amplification was: 1 cycle of $95^{\circ} \mathrm{C}$ for 5 minutes, 25 cycles of $94^{\circ} \mathrm{C}$ for 1 minute, $60^{\circ} \mathrm{C}$ for 1 minute, $72{ }^{\circ} \mathrm{C}$ for 1 minute, and 1 cycle of $72^{\circ} \mathrm{C}$ for 10 minutes and maintenance at $4{ }^{\circ} \mathrm{C}$. The second amplification was the same, using $5 \mu \mathrm{L}$ of the first amplification product.

The product of each amplification was applied to $2 \%$ agarose gel prepared in TAE 1X buffer $\left(\mathrm{LGC}^{\circledR}\right)$ and subjected to electrophoresis at a constant voltage of $100 \mathrm{~V}$ for 1 hour. The amplicons were visualized with ultraviolet light after ethidium bromide $\left(5 \mu \mathrm{g} \cdot \mathrm{mL}^{-1}\right)$ staining. The DNA fragment size was compared with a standard molecular weight (100 bp DNA ladder - FERMENTAS ${ }^{\circledR}$.

The agreement among the diagnostic tests (IHC, nested-PCR PLUS, and nested-PCR JB) was calculated by kappa statistics, using WIN Episcope version 2.0 (WIN EPISCOPE, 2000) with a confidence level of $95 \%$.

\section{Results and Discussion}

In the present study convenience sampling was used, and the diagnosis of abortion by $N$. caninum was based on the presence of histological lesions, positive reaction in IHC, and nested-PCR (JB and PLUS).

Histology was used as an initial screen for indication of infectious abortion. A mononuclear inflammatory infiltrate was predominant in the heart, kidney, liver, lung, brain, and placenta. According to Dubey, Lindsay, and Speer (1998), tachyzoites or cysts of $N$. caninum are rarely sufficiently numerous to be found in all histological sections from an animal, requiring the use of specific and sensitive tests to detect the parasite. For this reason, histopathology should be interpreted as complementary to tests such as IHC and nested-PCR, which identify the causative agent.

$N$. caninum causes mononuclear inflammatory infiltrate in various organs and focal necrosis with mononuclear infiltrate in the brain (PESCADOR et al., 2007). In the present study, in 38 cases of abortion that presented histological lesions in the brain (Figure 1), 4 were IHC positive (10.5\%). These results are consistent with other studies showing that the brain is the organ of choice for the detection of the parasite, since it is the most often affected, and any part of it can be used for histological examination (Table 1) (DUBEY; LINDSAY, 1996; DUBEY, 2003; PESCADOR et al., 2007). Positive results in the heart were observed with IHC in 2 of $53(3.8 \%)$ samples showing non-suppurative myocarditis, with histopathological lesions seen in only 1 of those samples (Table 1). In this case, abortion could have been due to vertical transmission of the parasite (DUBEY, 2003; DUBEY; SCHARES; ORTEGA-MORA, 2007). Söndgen et al. (2001) believe that in some cases, the infection by $N$. caninum can lead to fetal death before lesions develop.

Non-suppurative lesions were also present in the lung, liver, kidney, and placenta, indicating that $N$. caninum infection is systemic and can reach various tissues and fetal annexes.

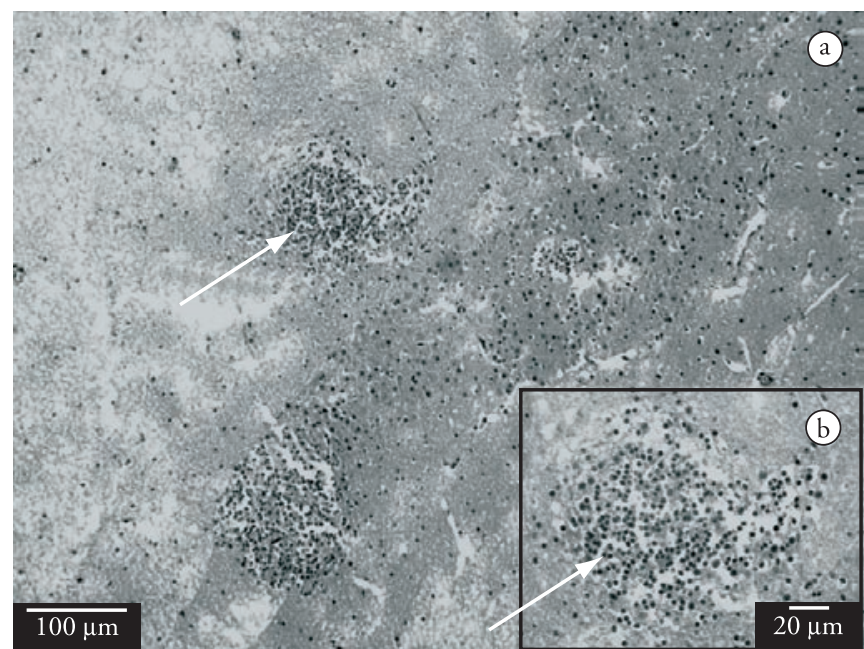

Figure 1. Multifocal necrotizing nonsuppurative encephalitis in the brain of an aborted bovine fetus (H\&E stain).

Corbellini et al. (2002) and Pescador et al. (2007) found non-suppurative lesions in various fetal organs testing positive with IHC. In the present study, histopathological lesions were observed in all brain samples positive with nested-PCR PLUS and nested-PCR JB.

Due the similarity between $N$. caninum and other coccidia (Toxoplasma gondii and Hammondia heydorni), molecular characterization has been performed with sequencing of ITS1 DNA, allowing inter- and intra-species differentiation. The study by Gondim et al. (2004b) showed that the sequencing of ITS1 can be applied as a complementary tool in the identification of species and strains of Neospora. Several studies have shown that the ITS1 region is a good marker for distinguishing members of the family Sarcocystidae (HOLMDAHL; MATTSON, 1996; PAYNE; ELLIS, 1996; MONTEIRO et al., 2007; BARRATT et al., 2008). The use of the ITS1 DNA region ensures the specificity of the test in the detection of $N$. caninum and BLAST analysis confirmed that the primers of the ITS1 region of the nested-PCR JB were specific to this parasite, so no cross reaction occurred with other coccidians. The sequence of primers from the Nc5 region is not found in the genomes of T. gondii, Sarcocystis capracanis, S. cruzi, S. miescheliana, S. moulei, S. tenella, or Hammondia hammondi (YAMAGE; FLECHTNER; GOTTSTEIN, 1996; HUGHES et al., 2006), showing that PCR PLUS has analytic specificity, too. Nested-PCR PLUS detected 22.2\% (16/72) of histologically positive brain samples. This result is similar to that obtained by GOTTSTEIN et al. (1998), who also used primers from the Nc5 region (genomic DNA) and detected N. caninum DNA in the brain of $29 \%$ of 83 aborted bovine fetuses in Sweden using nested-PCR (Table 2). Paula et al. (2004) employed hemi-nested-PCR, using primers of the Nc5 region, and found $N$. caninum in $31.3 \%$ of 32 samples of frozen brain tissue from aborted fetuses in Brazil.

Nested-PCR JB detected 6.9\% infected brain samples, a lower value than that published by Medina et al. (2006) in Mexico, who also used nested-PCR (primer of the ITS1 region of ribosomal DNA) and found a rate of $80 \%$ positivity in samples of infected 
Table 1. Neospora caninum in placenta and different tissues of aborted bovine fetuses tested with immunohistochemistry (IHC), with or without histopathological lesions.

\begin{tabular}{lccc}
\hline \multirow{2}{*}{ Organ } & \multicolumn{2}{c}{ Positive IHC } & \multirow{2}{*}{ Number of organs examined } \\
\cline { 2 - 3 } & With lesions & Without lesions & 68 \\
Brain & $10.5 \%(4 / 38)^{*}$ & $0.0 \%(0 / 30)$ & 22 \\
Placenta & $9.1 \%(1 / 11)$ & $0.0 \%(0 / 11)$ & 70 \\
Heart & $3.8 \%(2 / 53)$ & $5.9 \%(1 / 17)$ & 84 \\
Kidney & $1.8 \%(1 / 55)^{*}$ & $0.0 \%(0 / 29)$ & 90 \\
Liver & $1.7 \%(1 / 58)$ & $0.0 \%(0 / 32)$ & \\
\hline
\end{tabular}

*Brain and kidney of the same fetus positive.

Table 2. Positivity of Neospora caninum by nested-PCR (PLUS and JB) observed in placenta and different tissues from aborted bovine fetuses.

\begin{tabular}{lccccc}
\hline \multirow{2}{*}{ Organ } & \multicolumn{2}{c}{ Nested-PCR PLUS } & \multicolumn{2}{c}{ Nested-PCR JB } \\
\cline { 2 - 5 } \cline { 2 - 5 } Prain & $\%$ & Positive/Total & \% & $(5 / 72)$ \\
Placenta & 22.2 & $(16 / 72)$ & 6.9 & $(1 / 20)$ \\
Heart and liver & 20.0 & $(4 / 20)$ & 5.0 & $(2 / 49)$ \\
Pooled organs* & 16.3 & $(8 / 49)$ & 4.1 & $(2 / 64)$ \\
\hline
\end{tabular}

*Lung, kidney, spleen.

brain tissue of aborted fetuses from dairy herds. The positive rate of $8.8 \%$ using IHC in the present study was lower than that found by Pescador et al. (2007), 21.3\% (55/258), in Rio Grande do Sul, South Brazil. In Argentina, Moore et al. (2008) found a $7.4 \%$ (49/666) positive rate in fetuses by IHC, values close to those found in this work. The occurrence of bovine abortion resulting from $N$. caninum as diagnosed by IHC ranged from $4.2 \%$ in England and Northern Ireland (OTTER et al., 1995; McNAMEE et al., 1996) to $19 \%$ in California (ANDERSON et al., 1991).

The rate of fetal infection with $N$. caninum, represented separately by each of the diagnostic techniques, was $8.6 \%$ with IHC, $20.9 \%$ with nested-PCR PLUS, and $6.7 \%$ with nested-PCR JB. It is important to evaluate agreement among the techniques to interpret the value of these results.

Comparing IHC with nested-PCR PLUS, the 0.3 kappa coefficient (confidence interval 0.079 to 0.526 ) was consistent with a low degree of agreement, and between IHC and nested-PCR $\mathrm{JB}$, the 0.19 kappa coefficient (confidence interval -0.105 to 0.4830) indicated no significant agreement. Sager et al. (2001) also reported a weak correlation between PCR and IHC in 47 cases shown positive by PCR. Five of these cases showed no lesions consistent with those caused by $N$. caninum, and none of these cases were positive with IHC. Molecular techniques detect DNA in small quantities of fetal samples, whatever their condition, whether mummified or in varying degrees of autolysis.

Nested-PCR JB detected fetal infection at lower rates, 6.7\%, when compared with nested-PCR PLUS, 20.9\%, and the kappa coefficient of 0.35 (confidence interval 0.126 to 0.57 ) confirmed a low agreement. As the protocol for extraction of DNA was the same in both techniques, the lower threshold of detection of nested-PCR JB compared to the nested-PCR PLUS may be related to the primers used and to the gene region amplified.

The low values of kappa coefficients among the tests show that the techniques are complementary and demonstrate the need to calculate the rate of fetal infection by taking into account at least one positive result for each of the techniques (Table 3). Thus, 24.8\% of samples were positive for at least one of the techniques (IHC, nested-PCR, or nested-PCR PLUS JB). On the other hand, only $2.9 \%$ were positive with IHC, $11.4 \%$ with nested-PCR PLUS, and $0.9 \%$ with nested-PCR JB. The percent of samples positive for both IHC and nested-PCR PLUS was 3.8\%; none tested positive for both IHC and nested-PCR JB; and 3.8\% showed positive results for both nested-PCR PLUS and JB. In 1.9\% of samples there was a positive result for all three techniques. Pereira-Bueno et al. (2003) also concluded that it is necessary to use more than one diagnostic method to increase the probability of detection of the parasite in aborted fetuses. Baszler et al. (1999) suggested a protocol for the routine diagnosis of $N$. caninum in aborted bovine fetuses employing histopathology and the identification of the parasite by PCR and IHC, as in the present work.

Samples of fetuses and placentas sent to the Instituto Biológico for diagnosis of bovine abortion were often frozen and/or autolysed, hampering histopathological and IHC diagnosis. Freezing and autolysis destroy the cellular architecture of the parasite, which explains the non-visualization of structures (cysts or tachyzoites) by IHC, a technique that combines morphology and antigen-binding antibodies marked with chromogen. The IHC is a specific technique that has low sensitivity and can be effective when applied to intact tissues and those well fixed in formalin (EPERON et al., 1999). Fixing of the tissue with formalin can also interfere with the immunoreactivity of the sample, since it forms multiple connections with proteins (methylene bridges), which masks the epitopes and blocks access of antibodies to the antigen. For this reason enzymatic or heat methods should be used that facilitate antigen retrieval by destroying methylene bridges and improving immunoreactivity (BOENISCH, 2005; KEY; BOENISCH, 2006; RAMOS-VARA et al., 2008). 
Table 3. Fetal infection rates with Neospora caninum identified by each method, in 105 samples examined from January 2006 to May 2008.

\begin{tabular}{lcc}
\multicolumn{1}{c}{ Direct diagnosis } & Number positive & \% positive in total examined \\
\hline IHC & 3 & 2.9 \\
Nested-PCR PLUS & 12 & 11.4 \\
Nested-PCR JB & 1 & 0.9 \\
IHC and nested-PCR PLUS & 4 & 3.8 \\
IHC and nested-PCR JB & 0 & 0.0 \\
Nested-PCR PLUS and JB & 4 & 3.8 \\
IHC and nested-PCR PLUS and nested-PCR JB & 2 & 1.9 \\
Total & 26 & 24.8 \\
\hline
\end{tabular}

Another factor that may be contributing to discrepancies in the detection rate of techniques is the tissue sampling. When fragments were trimmed out, one for histopathology and another for molecular analysis, the parasite may have been present in one portion, but not in the other.

With respect to PCR, a possible explanation for the non-detection of DNA in some fetal organs shown positive with IHC may be degradation of DNA by autolysis (SHIBATA, 1994). Freezing does not affect DNA, and nested-PCR is thus a useful tool when tissues are frozen, whereas it complicates histological analysis.

The diagnosis of abortion due to $N$. caninum requires detection of the parasite through techniques that are specific, such as IHC, or ones such as PCR that are both specific and more sensitive, preferably associated with identification of histopathological lesions (SAGER et al., 2001). Efforts to collect organs that are as fresh as possible, including placenta and, importantly, fetal brain, should be encouraged to increase the success of the definitive diagnosis of neosporosis by tests of nested-PCR and IHC.

\section{Acknowledgement}

We thank Dr. Milton McAllister, from the College of Veterinary Medicine of Illinois University, USA, for the paraffin block positive control and primary polyclonal antibody against $N$. caninum for immunohistochemistry.

\section{References}

ANDERSON, M. L. et al. Neospora-like protozoan infection as a major cause of abortion in California dairy cattle. Journal of the American Veterinary Medical Association, v. 198, n. 2, p. 241-244, 1991.

BARRATT, J. et al. The development and evaluation of a nested PCR assay for detection of Neospora caninum and Hammondia heydorni in feral mouse tissues. Molecular and Cellular Probes, v. 22, n. 4, p. 228-233, 2008.

BASZLER, T. V. et al. Detection by PCR of Neospora caninum in foetal tissues from spontaneous bovine abortions. Journal of Clinical Microbiology, v. 37, n. 12, p. 4059-4064, 1999.

BJERKÅS, I.; MOHN, S. F.; PRESTHUS, J. Unidentified cyst-forming sporozoon causing encephalomyelitis and myositis in dogs. Zeithschrifft Fuer Parasitenkunde, v. 70, n. 2, p. 271-274, 1984.
BOENISCH, T. Effect of heat-induced antigen retrieval following inconsistent formalin fixation. Applied Immunohistochemistry \& Molecular Morphology, v. 13, n. 3, p. 283-286, 2005.

COLLANTES-FERNÁNDEZ, E. et al. Quantitative detection of Neospora caninum in bovine aborted fetuses and experimentally infected mice by real-time PCR. Journal of Clinical Microbiology, v. 40, n. 4, p. 1194-1198, 2002.

CORBELLINI, L. G. et al. Neosporosis as a cause of abortion in dairy cattle in Rio Grande do Sul, southern Brazil. Veterinary Parasitology, v. 103, n. 3, p. 195-202, 2002.

DUBEY, J. P. Review of Neospora caninum and neosporosis in animals. The Korean Journal of Parasitology, v. 41, n. 1, p. 1-16, 2003.

DUBEY, J. P. et al. Newly recognized fatal protozoan disease of dogs. Journal of the American Veterinary Medical Association, v. 192, n. 9 , p. 1269-285, 1988.

DUBEY, J. P.; LINDSAY, D. S. A review of Neospora caninum and neosporosis. Veterinary Parasitology, v. 67, n. 1, p. 1-59, 1996.

DUBEY, J. P.; LINDSAY, D. S.; SPEER, C. A. Structures of Toxoplasma gondii tachyzoites, bradyzoites and sporozoites and biology and development of tissue cysts. Clinical Microbiology Reviews, v. 11, n. 2, p. 267-299, 1998

DUBEY, J. P.; SCHARES, G.; ORTEGA-MORA, L. M. Epidemiology and control of neosporosis and Neospora caninum. Journal of Clinical Microbiology, v. 20, n. 2, p. 323-367, 2007.

EPERON, S. et al. Susceptibility of B-cell deficient C57BL/6 (microMT) mice to Neospora caninum infection. Parasite Immunology, v. 21, n. 5 , p. 225-36, 1999.

GONDIM, L. F. P. et al. Neospora caninum infection in an aborted bovine foetus in Brazil. New Zealand Veterinary Journal, v. 47, n. 1, p. 35, 1999.

GONDIM, L. F. P. et al. Variation of the internal transcribed spacer 1 sequence within individual strains and among different strains of Neospora caninum. Journal of Parasitology, v. 90, n. 1, p. 119-122, 2004 b.

GONDIM, L. F. P. et al. Coyotes (Canis latrans) are definitive hosts of Neospora caninum. International Journal for Parasitology, v. 34, n. 2, p. 159-161, 2004a.

GOTTSTEIN, B. et al. Molecular and immunodiagnostic investigations on bovine neosporosis in Switzerland. International Journal for Parasitology, v. 28, n. 4, p. 679-691, 1998. 
HOLMDAHL, O. J. M.; MATTSSON, J. G. Rapid and sensitive identification of Neospora caninum by in vitro amplification of the internal transcribed spacer 1. Parasitology, v. 112, n. 2, p. 177-182, 1996.

HUGHES, M. J. et al. The prevalence of Neospora caninum and coinfection with Toxoplasma gondii by PCR analysis in naturally occurring mammal populations. Parasitology, v. 132, n. 1, p. 29-36, 2006.

KEY, M.; BOENISCH, T. Antigen Retrieval. In: KEY, M. (ed.). Immunohistochemical staining methods. 4 ed. Carpinteria: Dako Corporation, 2006. p. 41-45.

KIRKBRIDE, C. A. Laboratory diagnosis of livestock abortion. 3 ed. Iowa State: University Press, 1990. 260 p.

LINDSAY, D. S.; DUBEY, J. P. Immunohistochemical diagnosis of Neospora caninum in tissue sections. American Journal of Veterinary Research, v. 50, n. 11, p. 1981-1983, 1989.

McALLISTER, M. M. et al. Dogs are definitive hosts of Neospora caninum. International Journal for Parasitology, v. 28, n. 9, p. $1473-1478,1998$.

MEDINA, L. et al. Survey of Neospora caninum infection by nested PCR in aborted fetuses from dairy farms in Aguascalientes, Mexico. Veterinary Parasitology, v. 136, n. 3-4, p. 187-191, 2006.

McNAMEE, P. T. et al. The diagnosis and prevalence of neosporosis in Northern Ireland cattle. The Veterinary Record, v. 138, n. 17, p. 419-420, 1996.

MONTEIRO, R. M. et al. Molecular phylogenetic analysis in Hammondia-like organisms based on partial Hsp70 coding sequences. Parasitology, v. 134, n. 9, p. 1195-1203, 2007.

MOORE, D. P. et al. The role of Neospora caninum and Toxoplasma gondii in spontaneous bovine abortion in Argentina. Veterinary Parasitology, v. 156 , n. 3-4, p. $163-167,2008$.

OTTER, A. et al. A survey of the incidence of Neospora caninum infection in aborted and stillborn bovine fetuses in England and Wales. The Veterinary Record, v. 136, n. 24, p. 602-606, 1995.

PAULA, V. S. O. et al. Evaluation of a PCR based on primers to Nc5 gene for the detection of Neospora caninum in brain tissues of bovine aborted fetuses. Veterinary Research Communications, v. 28, n. 7, p. $581-585,2004$.

PAYNE, S.; ELLIS, J. Detection of Neospora caninum DNA by the polymerase chain reaction. International Journal for Parasitology, v. 26, n. 4, p. 347-351, 1996.
PEREIRA-BUENO, J. et al. Evaluation by different diagnostic techniques of bovine abortion associated with Neospora caninum in Spain. Veterinary Parasitology, v. 111, n. 2-3, p. 143-152, 2003.

PESCADOR, C. A. et al. Histopathological and immunohistochemical aspects of Neospora caninum diagnosis in bovine aborted fetuses. Veterinary Parasitology, v. 150, n. 1-2, p. 159-163, 2007.

RAMOS-VARA, J. A. et al. Suggested guidelines for immunohistochemical techniques in veterinary diagnostic laboratories. Journal of Veterinary Diagnostic Investigation, v. 20, n. 4, p. 393-413, 2008.

SAGER, H. et al. A Swiss case-control study to assess Neospora caninumassociated bovine abortions by PCR, histopathology and serology. Veterinary Parasitology, v. 102, n. 1-2, p. 1-15, 2001.

SANTOS, A. P. M. E. et al. Neospora caninum in dairy cattle in Paraná State, Brazil: histological and immunohistochemical analysis in fetuses. Semina: Ciências Agrárias, v. 26, n. 4, p. 559-562, 2005.

SCHARES, G. et al. The efficiency of vertical transmission of Neospora caninum in dairy cattle analysed by serological techniques. Veterinary Parasitology, v. 80, n. 2, p. 87-98, 1998.

SHIBATA, D. Preparation of nucleic acids from archival material. In: MULLIS, K. B.; FERRE, F.; GIBBS, R. A. (Eds.). The polymerase chain reaction. Boston: Birkhauser, 1994. p. 47-54.

SÖNDGEN, P. et al. Bovine neosporosis: immunoblot improves foetal serology. Veterinary Parasitology, v. 102, n. 4, p. 279-290, 2001.

THILSTEAD, J. P.; DUBEY, J. P. Neosporosis-like abortions in a herd of dairy cattle. Journal of Veterinary Diagnostic Investigation, v. 1, n. 3, p. 205-209, 1989.

WIN EPISCOPE, 2000. Disponível em: http://www.clive.ed.ac.uk/ winepiscope/.

WOUDA, W. et al. Bovine fetal neosporosis: a comparison of epizootic and sporadic abortion cases and different age classes with regard to lesion severity and immunohistochemical identification of organisms in brain, heart, and liver. Journal of Veterinary Diagnostic Investigation, v. 9, n. 2, p. 180-185, 1997.

YAMAGE, M.; FLECHTNER, O.; GOTTSTEIN, B. Neospora caninum: specific oligonucleotide primers for the detection of brain "cyst" DNA of experimentally infected nude mice by the polymerase chain reaction (PCR). Journal of Parasitology, v. 82, n. 2, p. 272-279, 1996. 